\title{
Research on Agri-Food Cold Chain Logistics Management System: Connotation, Structure and Operational Mechanism
}

\author{
Jiuyi An1, Lei Wang' ${ }^{2}$ Xiaohua Lv ${ }^{1}$ \\ ${ }^{1}$ Beijing Wuzi University, Beijing, China \\ ${ }^{2}$ Beijing Benz Automotive Co. Ltd., Beijing, China \\ Email: anjiuyi@126.com
}

Received 2 December 2015; accepted 26 December 2015; published 29 December 2015

Copyright (C) 2015 by authors and Scientific Research Publishing Inc.

This work is licensed under the Creative Commons Attribution International License (CC BY). http://creativecommons.org/licenses/by/4.0/

(c) $\underset{\mathrm{EY}}{0}$ Open Access

\begin{abstract}
Along with the demand of development, this paper will define agri-food cold chain logistics management system. It is a general term of management system, organization system, standard system, running mechanism, etc. According to the activities and characters of agri-food cold chain logistics, the content of agri-food cold chain logistics management system includes three levels of management activities. There are macro management and part of the industry management of the government-led agricultural cold chain logistics activity, industry management of industry association as the main body, and micro enterprise operation management of enterprise as the main body. In addition, this paper will draw lessons from the city of agricultural products cold chain logistics management experience in the international, the main behavior of the logistics market, strengthen monitoring and early warning, strengthen the whole process, and make market access strictly and other key links have to be closely surrounded. Through improving agricultural products cold chain logistics management laws and regulations system, standard system, management system, testing system, certification system, technology supporting system, information service system, and establishing emergency mechanism and other agricultural products cold chain logistics security support system, government, industry, consumers, media, education and scientific research institutions and other relevant parties can take many aspects, many angles, many levels mutually supporting measures, in order to establish and improve the agricultural products cold chain logistics safety control system, and establish the whole process control system from farm to table, to ensure the safety of agricultural products cold chain logistics.
\end{abstract}

\section{Keywords}

Fresh Agricultural Products, Management System of Cold Chain Logistics, Operational Mechanism 


\section{Introduction}

In recent years, along with the structure adjustment of agriculture and the improvement of level of consumption, the production and circulation of fresh agricultural products increase year by year; the whole society puts forward higher requirements on safety and quality of fresh agricultural products, so as to drive the rapid development of cold chain logistics. The state attaches great importance to the development of cold chain logistics. In recent years the No. 1 document of the Central Committee had stressed the need to accelerate the construction of cold chain logistics system of agricultural products, and promote the circulation of agricultural products. Some national standards, industry standards and local standards of cold chain logistics have been issued and carried out. "Food Safety Law" and other important laws and regulations are gradually perfect. But our management of cold chain logistics of agricultural products is still in its early stage, and the systematic cold-chain logistics management system has not yet formed. However, China's cold chain logistics management of agricultural products is still in its initial stage; the system of the cold chain logistics management system has not yet formed. The research on the connotation, structure and operation mechanism of the cold chain logistics management system of fresh agricultural products has certain theoretical and practical significance.

\section{The Connotation and Characteristics of Management System of Cold Chain Logistics of Agricultural Products}

The definition of agri-food cold chain logistics management system is a special supply chain system. It collect the meat, poultry, aquatic products, vegetables, fruits, eggs, fresh agricultural products from origin of harvest, slaughter or fishing, then let the products process, storage, transportation, distribution, retail always in a suitable environment of low and control temperature, its aim is to extremely ensure the quality of product and quality safety, reduce loss and prevent the pollution that in a special supply chain system [1].

Agri-food cold chain logistics is a chain network system which "from farm to table", the system is made of the producers (farmers/production base) of agricultural products, the purchasing and processing enterprise of agricultural products, the distribution enterprise of agricultural products, the subject of cold chain logistics activity of agricultural products. The work of cold chain logistics of agricultural products includes products production, processing, and distribution, those are happen in the process of transportation, storage, loading and unloading, handling, packaging, distribution, information processing, etc.

According to the sorted of the cold chain logistics activities of agricultural products, this paper will define agricultural products' cold chain logistics management system as a general designation of management system, organization system, standard system, running mechanism, and so on, which in order to perform the industry regulatory responsibilities, build industry healthy and orderly market environment, ensure the quality of product quality and safety. Above those are according to the requirements of the market economy system efficient allocation of resources, and aim to adapt to the development of modern circulation of agricultural products demand. Combine the property of cold chain logistics activity of agricultural products with the definition of the connotation, the category of agricultural products' cold chain logistics management includes three levels management activities, they are macro management of government-led cold chain logistics activity of agricultural products and some industry management, industry management that the industry association act as the main body and the enterprising micro operation management that enterprises act as the main body.

The basic connotation of cold chain logistics management system of agricultural products includes the following meanings:

1) Operation mechanism is the soul of the management system. If has no Decision-making, implementation, feedback and other continuous operating activities, the cold chain logistics management system of agricultural products cannot work and have none value. The cold chain logistics management system of agricultural products rely on legal and administrative means to regulate and control the main body of market, through the government enforcement regulation or economic means to guide the market to form industry self-discipline mechanism and control mechanism of the enterprises. Through perfect the laws and standards to establish the quality inspection and supervision mechanism.

2) The organizational structure of cold chain logistics management system of agricultural products is the forms of management system. The organizational structure is the carrier of management function, if has no organization, management system is impossible. The existing cold chain logistics system of agricultural products 
builds organizational structure according to departments build the government organizational structure, industry association in accordance with the link of cold chain logistics and the product categories.

3) The core content of cold chain logistics management of agricultural products is the division of management responsibilities in the management system and the configuration of the management functions. The division of management responsibilities decides the configuration of the management functions, and the configuration of the management functions affects the work of system. The current management system takes governmental agricultural departments at all levels, health department, quality checking department, food and drug quality supervision department, the ministry of commerce and industry and so on as the main body, takes the industry associations and a variety of chamber of commerce that the government authorized them parts industry management, market entity as the architecture of auxiliary system.

4) Legal norms are integral parts of management system, the operation of the cold chain logistics management system of agricultural products takes influenced and restriction of the environment of laws and regulations. At present, it has established the legal framework with Law of Agricultural Produce Quality Safety, Farm Bill and other basic law as the main body, continuously strengthens the cohesion of department regulations and the operation of local laws and regulations, to speed up the legalization process of cold chain logistics management of agricultural products. The core construction of standard system is aim to develop and promote a batch of specific operation and technology standard of cold chain logistics of agricultural products, to establish the whole quality control system on the basis of HACCP, to develop specific operation and technology standard of agricultural products' cold chain logistics that in line with international standards.

Our cold chain logistics management system of agricultural products has the following basic features:

The first is the diversification of management. There are many links, participation, small scale, scattered and other characteristics in the agricultural production and circulation, it decides the main body is diversified in the cold chain logistics management of agricultural products. The main body of cold chain logistics management of agricultural products is made of the government at all levels that leading management, the industry association of auxiliary participation and industry management, business enterprise, etc. On one hand, the cold chain logistics management of agricultural products strength the government mandatory regulation; on the other hand, it gradually authorizes industry association industry management, gives full play to the role of the industry self-discipline, actively guides enterprise self-control and encourages social supervision.

The second is thorough regulatory. Along with the social attention to the quality and safety of agricultural products, consumers are demanding products whole process of the supply chain that from farm to table should be strictly regulated. Law of Agricultural Produce Quality Safety says: "Administrative departments of agriculture of the people's governments at or above the county level are responsible for the supervision and administration of the quality and safety of agricultural products, the relevant departments of the people's governments at or above the county level depend the responsibilities to devise the labor, and take responsible for the work of the quality and safety of agricultural products.” It confirms the relevant departments' safety regulatory functions and responsibilities of the cold chain logistics of agricultural products, gradually establishes a management system in the whole process of the "from farm to table" [2].

The third is the information is visualized all the way. The process and span of the cold chain logistics management of agricultural products is giant, many participative and administrative main bodies, transmission of information easies to interrupt. Law of Agricultural Produce Quality Safety says: "The competent agricultural administrative departments of the State Council and the people's governments of provinces, autonomous regions and municipalities directly under the central government shall publish information on the quality and safety of agricultural products in accordance with their respective functions and powers." In addition, the business and the departments of agriculture take responsibility for expanding the pilot range of full traceability information platform of the cold chain logistics of agricultural products, gradually perfecting the multistage information tracing system. Except the government departments extensively release cold chain logistics information of agricultural products, the main participative bodies of cold chain logistics gradually strengthen information system construction, continuously strengthen information exchange and communication, strengthen the information sharing of cold chain logistics of agricultural products.

The fourth is management legalization and standardization. Legalization and standardization is the basic safeguard for the cold chain logistics management of agricultural products, and is the external driving force for specific management of the main body of cold chain logistics management of agricultural products. In recent 
years, our country continues to strengthen the construction of laws, regulations and standardization, makes the behavior of cold chain logistics management of agricultural products fully on the basis of legal and standard, and makes the legal business enterprises have full legal protection.

\section{Structure Analysis of Cold Chain Logistics Management System of Agricultural Products}

Cold chain logistics management system of agricultural products is a complex system. Its structure includes organizational system of cold chain logistics of agricultural products, supervision system of cold chain logistics of agricultural products, legal Standard system of cold chain logistics of agricultural products and industry public service system. In addition, the supervision system includes market access system, testing system and tracing system. The legal Standard system includes legal system, technical standards, specifications, application guidelines, etc. Aim to accurately grasp the internal logic relationship of each part and the operation mechanism through an analysis of internal structure and function of the cold chain logistics management system of agricultural products (Figure 1).

\subsection{Analysis of the Supervision System of Cold Chain Logistics of Agricultural Products}

The supervision system of agri-food cold chain logistics is generic terms of effective market activities. In the management activities, the government department or social organization of cold chain logistics of agricultural products through certain legal and institutional arrangements to maintain the normal order of market. In the process of cold chain logistics of agricultural products, agricultural products from production, processing, transportation, storage and other link to the consumer at last, based on each link of "from farm to table" to control market access, detection and tracing, to form the regulation and supervision for the operational main body of the market, to ensure the safety of service process of cold chain logistics of agricultural products. The supervision system includes tracing system, market access system, authentication system, inspection and testing system, etc. Looking from the content of the supervision system, supervision system of cold chain logistics of agricultural products includes macro supervision and concrete market supervision. The macro supervision is for the development of market of cold chain logistics and concrete market supervision. The concrete market supervision mainly includes: supervise the implementation of laws and regulations, maintain the order of fair competition in the market, to protect the benefit and interests of all kinds of market participator; strengthen the supervision of quality and safety of cold chain logistics of agricultural products, to maintain the interests of consumers; and strengthen the supervision of production safety of all kinds of cold chain logistics, to maintain the interests of labor [3].

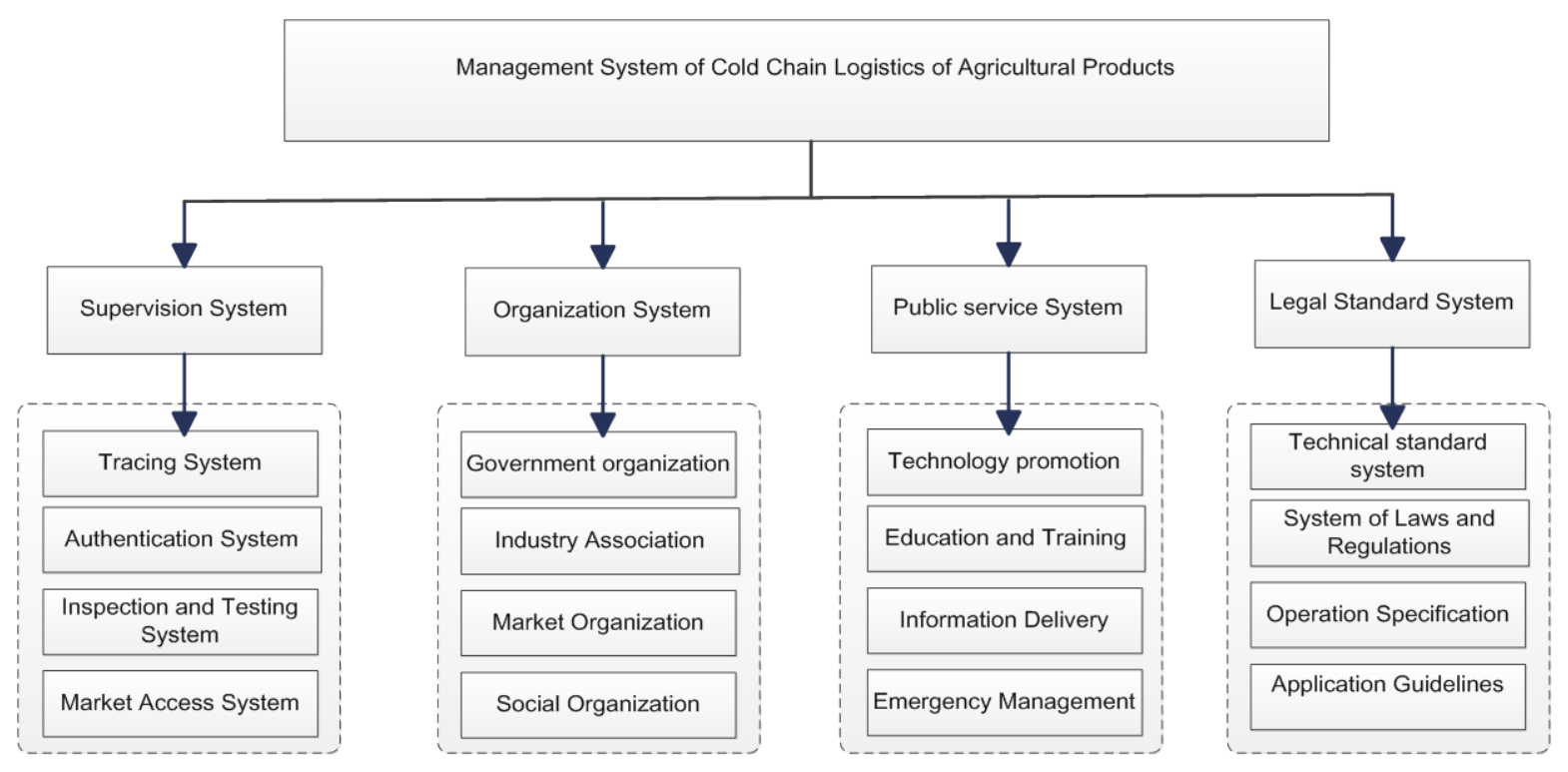

Figure 1. Framework of management system of cold chain logistics of agricultural products. 


\subsection{Analysis of the Organization System of Cold Chain Logistics of Agricultural Products}

The organization system of cold chain logistics of agricultural products is the carrier of activities of cold chain logistics management. According to the structure of the cold chain logistics system, the related functional departments of agricultural products' cold chain logistics of the government construct the basic frame of organization system.

This structure includes both horizontal government institutions, function configuration and the longitudinal central and local institutions, function configuration, mainly including government departments at all levels, health department, quality checking department, the ministry of commerce and industry, business department, the ministry of environmental protection, etc. and includes these departments' corresponding extension organization that set up in the province, city and county respectively. In addition, the organizations system of cold chain logistics of agricultural products includes industry association organization, market organization and other auxiliary institutions. According to the organization's operation, in order to realize the management function of normal and efficient that by a certain legal and system design to form the management system and mechanism of formation, and the person that in the management system.

\subsection{Analysis of the Cold Chain Logistics Industry Public Service System of Agricultural Products}

Public service system of cold chain logistics is surrounding the problem of solving the industry developing, the government provides all kinds frameworks of public service, as well as provides the means and methods of public service, etc.

According to the content and structure of the public service system, the public service of cold chain logistics of agricultural products in China mainly includes: industry public education and training services, industry public infrastructure services, industry public information services, etc. In addition, the establishment of a sound emergency management mechanism of cold chain logistics of agricultural products has become an important part of the cold chain logistics management. The establishment of emergency mechanism to handling the safety incidents of agricultural product has become the international practice, China should establish the emergency public service system of cold chain logistics, such as emergency awareness, emergency laws and regulations, emergency plan, store of emergency cold chain logistics resources and so on.

\subsection{Analysis of Laws, Regulations and Standards System of Cold Chain Logistics of Agricultural Products}

Laws, regulations and standards system of cold chain logistics of agricultural products combines the characteristic of the industry development of cold chain logistics of agricultural products and established the policy legal system of cold chain logistics of agricultural products of adapted market economy system, to provide legal basis and support for the participator of cold chain logistic and management activities.

Policy and legal system of cold chain logistics of modern agricultural products uses the national basic laws and regulations, rules and regulations of government of all levels to concretely lead and regulate the constitution of specialized laws and regulations, industry technology and management standards of cold chain logistics of agricultural products. Looking from the point of function, Laws, regulations and standards system of cold chain logistics of agricultural products is the main method of regulating the market main body, it is the supporting system of building the market legal environment of cold chain logistics of agricultural products as well. Looking from the point of running, to set up the whole management system of cold chain logistics of agricultural products on the basis of the laws and regulations of cold chain logistics of agricultural products supporting the system, in order to realize the seamless connection between the supervision of whole process and information of cold chain logistics activities, and ensures the quality safety of agricultural products, give the government, enterprises and the consumer with effective legal protection.

\section{The Operational Mechanism of Cold Chain Logistics Management System of Agricultural Products}

In the constructional aspect of management system, drawing on the experience of cold chain logistics management of foreign agricultural products, the government and social forces coordinately take participate in gover- 
nance has become the mainstream management system. In the construction of cold chain logistics management system of agricultural products in China, the government management department according to the characteristics of cold chain logistics activities, a clear division of government and society, and gradually form a sub full management system. At the same time, in the field of the government can not cover, or in the field of low efficiency in the role of government, the government gradually authorizes and plays the force of social organizations such as industry associations and other social organizations to participate in the industry management activities. The automatic control management of enterprises in the business activities gradually strengthens, market self-control awareness of supply and demand enterprises continually strengthens. Along with the social public and consumer awareness raising, the initiative of the government, social organizations, enterprises and other management entities and market players to participate in the supervision improves. Through the multi agent participation, the cold chain logistics management system of agricultural products is formed in the horizontal and vertical multi levels.

In the constructional aspect of laws, regulations and standards, China has formed the law system that such as Farm Bill, The Law of Agricultural Product Quality and Safety and other basic law system as main body, the basic legal construction has been strengthened, the making of regulations of departments focus on linking up each other, the establishment of local regulations focus on linking up the regulations that from the central to the local of all levels, increasing the integrity and operability of the legal system. In order to accelerate the construction of cold chain logistics standard system which is the main unit of the association, developing and promoting a batch of specific operation and technology standard of cold chain logistics of agricultural products, establishing the whole quality control system on the basis of HACCP, but laws, regulations, standards, guidelines and other mutual support and cohesion mechanism should be further strengthened.

In the regulatory system, the domestic government and the association gradually carry out HACCP, GMP, GAP (good agricultural practices), ISO (International Standard Organization) and other quality and safety certification system and market access system, enterprises begin to attach importance to the construction of standards and certification. Government and social forces increases investment year by year, improves the infrastructure building of the supervision and inspection of the cold chain logistics production, processing, storage, transportation, transit, import and export, and other major aspects. Overall, the cold chain logistics certification system just in the start, the market access system is still in the exploration stage, the construction of inspection and testing institutions to be strengthened, the information traceability system has a significant role in demonstration.

In the main body of market operation, because of the production and the circulation subject take small business as the main body, The operation of cold chain logistics of agricultural products still takes production, processing, distribution and other sub operations as main operational body, the whole process of cold chain logistics has developed in large chain enterprises and agricultural products leading enterprises. As a result, the main market operational body of cold chain logistics of agricultural products is still in the situation of the common participation that conjoining the operational enterprises of production and supply with the logistics enterprises of specific cold chain supply (Figure 2).

\section{The Goal of Constructing the Cold Chain Logistics Management System of Agricultural Products in the City}

Drawing lessons from the city of agricultural products cold chain logistics management experience in the international, the main behavior of the logistics market, strengthen monitoring and early warning, strengthen the whole process, make market access strictly and other key links have to be closely surrounded. Through improving agricultural products cold chain logistics management laws and regulations system, standard system, management system, testing system, certification system, technology supporting system, information service system, and establishing emergency mechanism and other agricultural products cold chain logistics security support system, government, industry, consumers, media, education and scientific research institutions and other relevant parties can take many aspects, many angles, many levels mutually supporting measures, in order to establish and improve the agricultural products cold chain logistics safety control system, and establish the whole process control system from farm to table, to ensure the safety of agricultural products cold chain logistics [4].

1) To establish a clear and coordinated management system of agricultural products cold chain logistics between government agencies. The basic requirement of the system of agricultural products cold chain management is the government's position to be accurate, from the farmland to the dining table to implement the full responsibility of the parties to be clear, all levels of management agencies has to be lean and efficient. 


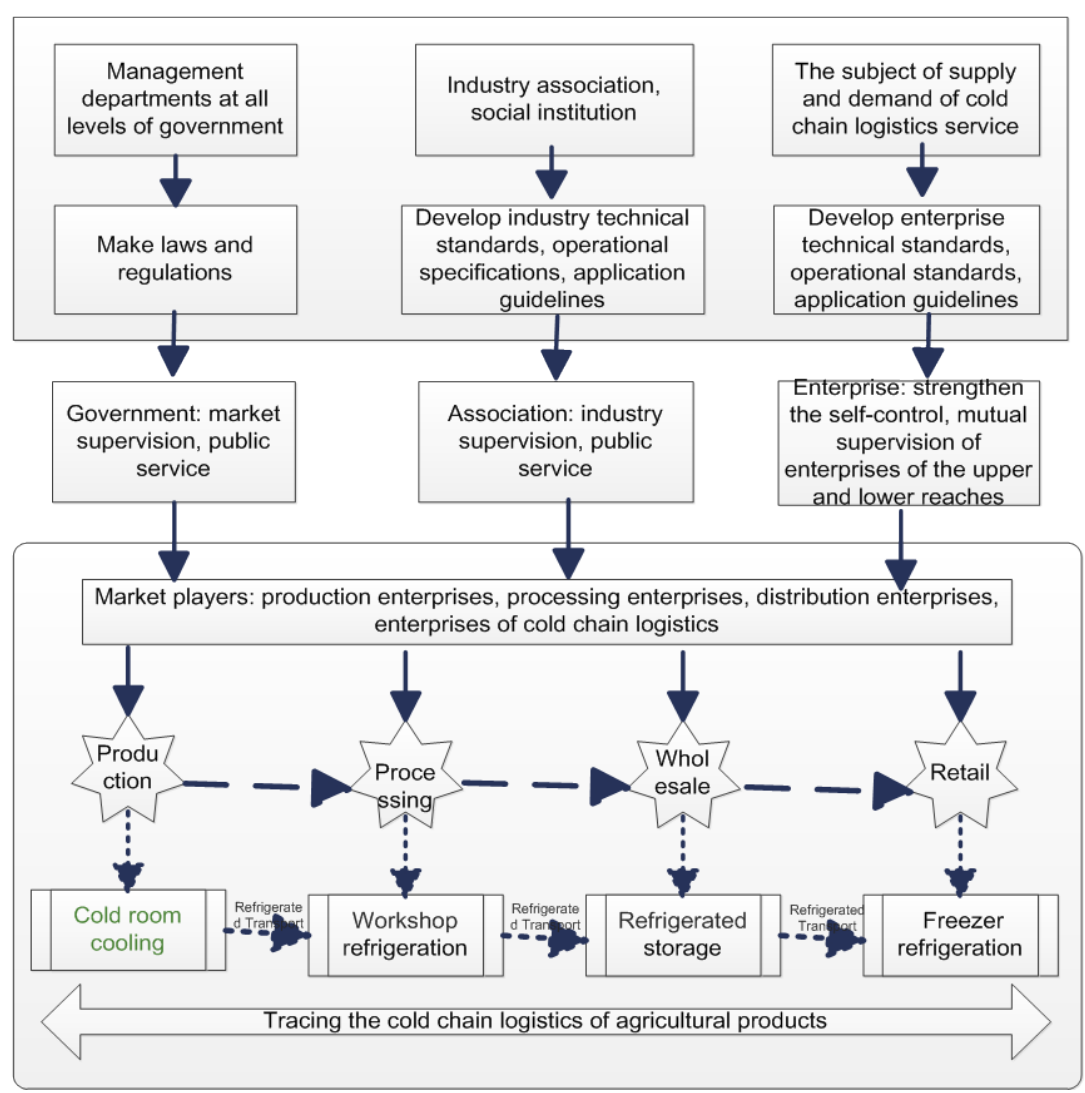

Figure 2. The operational mechanism of cold chain logistics management system of agricultural products.

2) Improving the technology level of agricultural products cold chain logistics management. The main factors affecting the safety of agricultural products cold chain logistics in China, and determined by the key technology. Research on the safety of cold chain logistics of agricultural products in the stage, the selection and the gradual development, priority develop energy saving, environmental protection, safety and cold chain logistics equipment technology, in order to further develop a more reliable, fast, portable, accurate detection technology, to speed up the development of agricultural production, processing, storage, packaging and transportation process of safety control technology. Preliminary establish cold chain logistics safety science and technology system to adapt to the development of modern agricultural products.

3) Improving the standard system of agricultural products cold chain logistics. In strengthening the unified management and give full play to the role of the relevant departments, to set up a set of agricultural products, which is in line with China's national conditions and international standards of cold chain logistics standard system. Activity using the international standards and foreign advanced standards actively and increase the intensity of international standards.

4) Establish a unified, authoritative and efficient inspection system for cold chain logistics inspection system of agricultural products. Drawing lessons from foreign experience and according to the principle of overall planning, reasonable layout, it has to establish a mutual coordination, division of labor is reasonable, function, technology, advanced, functional, personnel matching, running efficient cold chain logistics inspection system of agricultural products. In the detection range, it can meet the needs of production, processing and circulation of the whole process of the implementation of safety testing. In the detection ability, it also can meet the national standards, industry standards and relevant international standards for the agricultural products cold chain logistics parameters testing requirements. Relying on the existing monitoring and detection of resources, to further improve the main production base, processing base, distribution center, transit center, import and export port inspection and testing capabilities, improve the level of supervision, to ensure product's quality and safety.

5) To establish a unified and standardized system of agricultural products cold chain logistics certification and 
accreditation. In order to strengthen the whole process safety control, the material production, processing, transportation, sales enterprises in the food raw can promote the GPS system and HACCP system certification.

6) To establish and improve the emergency response mechanism of cold chain logistics of agricultural products. The establishment of emergency mechanism for handling the safety of agricultural products has become an international practice, China should establish a system of agricultural products cold chain logistics security emergency response mechanism from the establishment of laws and regulations system, improving the information collection, processing and dissemination mechanism.

7) To establish a unified and coordinated system of laws and regulations. We should learn from the experience of international agricultural products cold chain logistics laws and regulations, to establish the basic framework of China's agricultural products cold chain logistics safety regulations system, and to improve the existing laws and regulations system, giving law enforcement authorities more power, strengthen legislation and law enforcement supervision, etc.

8) Establish the cold chain logistics distribution system of agricultural products of urban and rural areas. Agricultural products cold chain logistics, from the farm to the table, as the main production base of the vast rural areas of the cold chain logistics system is an important part of the cold chain logistics. At the same time, the cold chain distribution system for the city's consumption driven type is also an essential part of cold chain logistics. Therefore, the construction of cold chain logistics system in urban and rural areas is the need to adapt to the development of modern agricultural products circulation, At the same time, it is an important task to construct the cold chain logistics distribution system for agricultural products, especially the construction of cold chain distribution system.

\section{Conclusion}

From what has been discussed above, firstly, according to the definition, activities and characters of agri-food cold chain logistics, the content of agri-food cold chain logistics management system is classified in three levels of management activities. There are macro management and part of the industry management of the government-led agricultural cold chain logistics activity, industry management of industry association as the main body, and micro enterprise operation management of enterprise as the main body. Secondly, cold chain logistics management system of agricultural products is a complex system. Its structure includes organizational system of cold chain logistics of agricultural products, supervision system of cold chain logistics of agricultural products, legal standard system of cold chain logistics of agricultural products and industry public service system. In addition, the supervision system includes market access system, testing system and tracing system. The legal standard system includes legal system, technical standards, specifications, application guidelines, etc. The aim is to accurately grasp the internal logic relationship of each part and the operation mechanism through an analysis of internal structure and function of the cold chain logistics management system of agricultural products. Finally, from the experience of international agricultural products cold chain logistics management, the regulatory authorities should strengthen the supervision of market behavior and early warning, strict market access, and the key to form a closed loop. Through improving agricultural products cold chain logistics management laws and regulations system, standard system, management system, testing system, certification system, technology supporting system, information service system, and establishing emergency mechanism and other agricultural products cold chain logistics security support system, government, industry, consumers, media, education and scientific research institutions and other relevant parties can take many aspects, many angles, many levels mutually supporting measures, in order to establish and improve the agricultural products cold chain logistics safety control system, and establish the whole process control system from farm to table, to ensure the safety of agricultural products cold chain logistics.

\section{Acknowledgements}

The fund project, the National Social Science Fund "The research of fresh agricultural products cold chain logistics management system for the needs of the city” (11BJY111).

\section{References}

[1] Reddy, C.M., Malliyala, S., Naresh, Y., Raghunandan, H.V. and Jinadatharaya, H. (2012) Good Cold Chain Management Practices. Journal of Pharmacy Research, 10, 5043-5047. 
[2] Li, C.J., Yang, C. and Liang, J. (2009) Analysis on the Dynamic Mechanism of Supervision of Agricultural Product Quality Safety. Journal of Guangxi University of Finance and Economics, 22.

[3] Jin, F.Z. (2011) Thinking on the Construction of Supervision and Business Support System of Agricultural Product Quality Safety. Quality and Safety of Agricultural Products, 6, 8-10.

[4] Zhang, B. and Weng, X.W. (2012) Function and Complexity of Supervision System of Agricultural Product Quality and Safety and Its Solution. Agricultural Modernization Analysis, 33, 59-63. 